\title{
Feeding di-ammonium phosphate as a phosphorous source in finishing lambs reduced excretion of phosphorus in feces without detrimental effects on animal performance
}

\author{
Abolfazl Koolivand', Mojtaba Yari ${ }^{1}{ }^{1 *}$, Saeed Khalaji', and Arjan Jonker ${ }^{2}$
}

\author{
* Corresponding Author: Mojtaba Yari \\ Tel: +98-9124479406, Fax: +98-8132355338, \\ E-mail: m.yari@malayeru.ac.ir \\ 1 Department of Animal Sciences, Malayer University, \\ Malayer 65719-95863, Iran \\ ${ }^{2}$ Grasslands Research Centre, AgResearch Ltd. \\ Palmerston North 4442, New Zealand \\ ORCID \\ Mojtaba Yari \\ https://orcid.org/0000-0002-8640-0608
}

Submitted Aug 7, 2017; Revised Nov 23, 2017; Accepted Dec 22, 2017
Objective: Phosphorous $(\mathrm{P})$ sources with greater bioavailability might increase animal production efficiency and decrease environmental pollution. The objective of current study was to determine animal performance, nutrient digestibility, blood metabolites and fecal P concentration in finishing lambs fed a diet with either di-calcium phosphate (DCP) or di-ammonium phosphate (DAP) as a $\mathrm{P}$ source.

Methods: Twelve 4-month-old male lambs (initial body weight $24.87 \pm 3.4 \mathrm{~kg}$ ) were randomly allocated to a diet with either DCP or DAP $(\sim 261 \mathrm{~g} / \mathrm{kg}$ of total diet P) fed ad libitum for 93 days. Diets were iso-nitrogenous and iso-energetic and had same calcium $(\mathrm{Ca})$ and $\mathrm{P}$ concentrations.

Results: The DAP contained $19.7 \mathrm{~g} / \mathrm{kg}$ of dry matter (DM) Ca, $185.4 \mathrm{~g} / \mathrm{kg}$ DM P and 14,623 ppm fluorine, while DCP contained 230.3 g/kg DM Ca, $195.2 \mathrm{~g} / \mathrm{kg}$ DM P and 1,039 ppm fluorine. The diet with DAP contained $60 \mathrm{ppm}$ fluorine while the diet with DCP contained $13 \mathrm{ppm}$ fluorine. Lambs fed the diet with DAP tended to have a greater daily DM intake compared to those fed diet with DCP $(\mathrm{p}=0.09)$. Lambs fed DAP had greater plasma P concentration and alkaline phosphatase activity $(\mathrm{p} \leq 0.01)$ compared with lambs fed DCP. Dry matter and organic matter digestibility of the diets were similar between two treatments at days 60 and 90 , while they were greater in lambs fed DCP $(\mathrm{p}<0.05)$ at day 30 of the trial. Feeding DAP increased $\mathrm{P}$ digestibility $(58.7 \%$ vs $50.2 \%$; $\mathrm{p}<0.05)$ and decreased fecal $\mathrm{P}$ concentration in lambs compared with feeding DCP (3.1 vs $3.8 \mathrm{~g} / \mathrm{kg} \mathrm{DM} ; \mathrm{p}<0.05)$.

Conclusion: Providing $\sim 261 \mathrm{~g} / \mathrm{kg}$ of total diet P as DAP in the diet of finishing lambs improved the bioavailability of $\mathrm{P}$ in the body and decreased excretion of $\mathrm{P}$ in feces without affecting lamb performance.

Keywords: Di-ammonium Phosphate; Di-calcium-phosphate; Fecal Phosphorus; Lamb Growth

\section{INTRODUCTION}

Phosphorus $(\mathrm{P})$ is an essential mineral in the animal body (e.g. component of bone, many metabolic active compounds, genetic material and of cell structures) and therefore essential in the diet. Phosphorus is, however, an expensive mineral and represent a risk for environmental pollution [1,2]. Most of the $\mathrm{P}$ applied in agriculture as fertilizer or in feed is derived from phosphate rock reserves, a non-renewable resource, which are estimated to be depleted in 50 to 100 years [2]. Optimizing the supply of $\mathrm{P}$ in the animal diet and improving the $\mathrm{P}$ availability in the body when using different $\mathrm{P}$ sources offer an opportunity to reduce these impacts. However, deficiency in dietary $\mathrm{P}$ concentration or availability should be avoided to prevent metabolic disorders and poor livestock performance [3].

Di-calcium phosphate (DCP) is the common source of $\mathrm{P}$ in premixes for lamb rations 
[4]. Di-ammonium phosphate (DAP) contains very low calcium $(\mathrm{Ca})$, unlike DCP, which could improve formulation of diets with high levels of legume forages that contain high $\mathrm{Ca}$. Russell et al [3] and Parsad et al [5] reported that DAP can be used as a source of both $P$ and nitrogen in ruminant diets (containing $\sim 235.0 \mathrm{~g} / \mathrm{kg} \mathrm{P}$ and $\sim 212.0 \mathrm{~g} / \mathrm{kg}$ nitrogen). Fertilizer grade DAP might be a suitable $\mathrm{P}$ source for wintering diets of sheep, which are generally low in both $\mathrm{P}$ and $\mathrm{N}$ [6]. DAP is also cheaper than DCP [2]. Despite these potential beneficial properties of DAP, few studies have determined the effects of DAP in the diet of lambs. However, P sources may contain impurities (e.g. fluorine and heavy metals) that can cause toxic effects to the animal [6], which should be determined before its use in animal feeding.

We hypothesized that it would be possible to replace DCP as a common P source in the diet with DAP, without detrimental effects on the performance of growing lambs. The objectives of current study were to measure calcium, $\mathrm{P}$ and heavy metals concentration in DCP and DAP and to determine animal performance, nutrient digestibility, blood metabolites and fecal $\mathrm{P}$ concentration in finishing lambs fed a diet with either DCP or DAP as the P source.

\section{MATERIALS AND METHODS}

\section{Sheep management and feeding}

Twelve 4-month-old Mehraban male lambs (initial body weight [BW] $24 \pm 3.4 \mathrm{~kg})$ were housed in individual cages $(0.9 \times 1.5$ meter) during the current study. Lambs were vaccinated for antrotoxemia and foot and mouth disease, and orally drenched for internal parasites. A control diet was formulated according to NRC [1] recommendations and fed during the 2 weeks acclimatization period before the beginning of experiment. Feed dry matter intake (DMI) and BW were recorded during second week of this period, which were used as covariate for final statistical analysis. Lambs were randomly allocated to 2 dietary treatments containing either DCP or DAP as a $\mathrm{P}$ source. The both diet were formulated according to NRC [1] to have similar crude protein, metabolizable energy (ME), $\mathrm{Ca}$ and $\mathrm{P}$ concentrations (Table 1 ) and 261 and $305 \mathrm{~g} / \mathrm{kg}$ of $\mathrm{P}$ in the diets was supplied by either DCP or DAP and the rest from basal diet. The diets were fed ad libitum (30 to 50 $\mathrm{g} / \mathrm{kg}$ orts allowed) around 08:30 h every morning for 93 days.
Lambs had free access to water throughout the experiment. Lambs were weighed at day $0,21,30,44,62,78$, and 93 of the experiment before morning feeding. During experiments, vitamin supplements such as $\mathrm{A}, \mathrm{D}_{3}$, and $\mathrm{E}$ were not used in the diets due to carrier material used but they supplied through muscle injection. Animals in current study were cared for according to the guidelines of the Iranian Council of Animal Care [7].

\section{Sample analysis and nutrient digestibility}

Fecal grab samples were collected for 4 consecutive days (one per lamb per day) at day 30,60 , and 90 at $3 \mathrm{~h}$ after feeding. Fecal samples were dried at $50^{\circ} \mathrm{C}$ for $48 \mathrm{~h}$ and the 4 grab samples per lamb per each sampling period were pooled. At days of fecal sampling, feed samples from forage and concentrate portion (50 $\mathrm{g}$ from each portion) collected and mixed in the lab to make experimental diets. Diets were oven dried at $50^{\circ} \mathrm{C}$ for $48 \mathrm{~h}$ and ground through $1 \mathrm{~mm}$ before further analysis. Orts were collected to measure nutrient intake. Standard procedures described by AOAC [8] were used to determine DM, ash, calcium, and $\mathrm{P}$ concentration. Fecal samples were analyzed for acid insoluble ash according to Van Keulen and Young [9] and organic matter (OM) according to AOAC [8]. Acid insoluble ash was used as an internal marker to estimate digestibility in combination with measured $\mathrm{DM}, \mathrm{OM}$, and $\mathrm{P}$ [9]. In last period of sample collection, $\mathrm{P}$ concentration was measured in fecal samples for 4 consecutive days. The concentrations of fluorine, cadmium, lead, mercury and arsenic of DAP, DCP, and experimental diets were measured using a ContrAA 700 (Analaytikjena, Jena, Germany) by atomic absorption method according to procedures described by Jorhem [10].

\section{Blood sample collection}

On day 30, 62, and 93 blood samples were collected from the jugular vein of each lamb into heparinized tubes prior to feeding. Plasma Ca [11] and P [12] and serum glucose, urea nitrogen and alkaline phosphatase activity were measured using commercial kits (Pars Azmon Inc., Tehran, Iran). Glucose was measured using enzymatic photometric method [13]. Blood urea nitrogen was measured using Urease-GLDH method [14]. The alkaline phosphatase was measured using DGKC (Germany Biochemistry Association Standard) [15].

Table 1. Macro mineral $(\mathrm{g} / \mathrm{kg}$ ) and heavy metals (ppm) profile of di-calcium phosphate, di-ammonium phosphate and calcium carbonate used in the experimental diets of finishing lambs

\begin{tabular}{lccccccccc}
\hline Items & $\mathbf{C a}$ & $\mathbf{P}$ & $\mathbf{F}$ & $\mathbf{P b}$ & $\mathbf{H g}$ & $\mathbf{C d}$ & As & $\mathbf{P}: \mathbf{F}$ & ASP \\
\hline DCP & 230.3 & 195.2 & $1,039.1$ & 41.7 & 1.8 & 2.8 & 7.6 & 1.9 & 97.5 \\
DAP & 19.7 & 185.4 & $14,623.3$ & 3.8 & 1.7 & 2.7 & 6.5 & 12.7 & 96.6 \\
$\mathrm{CaCO}_{3}$ & 390.2 & 6.0 & 22.4 & 17.4 & 15.6 & 2.9 & 9.5 & 27.3 & ND \\
\hline
\end{tabular}

$P: F$, ratio of phosphorous to fluorine; ASP, acid soluble phosphorus; DCP, di-calcium phosphate; DAP, di-ammonium phosphate; ND, not determined. 
Also, photometric method by creolphthalein complex one for measuring calcium and photometric UV test for measuring $P$ degree were used. Biochemistry experiments were performed by Auto-Analyzer machine, Hitachi 717.

\section{Statistical analysis}

All data were analyzed by repeated measurements using Proc mixed of SAS 9.2 [16] using the following model:

$$
Y_{i j k}=\mu+T_{i}+P_{j}+l a m b_{k}+T_{i} \times P_{j}+e_{i j k}
$$

Where $Y_{i j k}$ is the observation of dependent variable; $\mu$ is the fixed effect of population mean for the variable; $T_{i}$ is the fixed effect of supplemented P source ( $\mathrm{i}=2, \mathrm{DCP}$ and DAP); $P_{j}$ is the fixed effect of sampling day $(j=3$ for blood and fecal samples and $\mathrm{j}=6$ for DMI and BW measurements); $T_{i} \times P_{j}$ is the interaction between factor $\mathrm{T}$ at level $\mathrm{i}$ and factor $\mathrm{P}$ at level $\mathrm{j}$; $\operatorname{lamb}_{k}$ is the random effect of lamb within treatment $(\mathrm{k}=6)$; and $e_{i j k}$ is the random error associated with the related observation.

The DMI and BW in the week before the beginning of the experimental treatments were included in the model as covariates. The covariate was excluded from the model when it was not significant $(\mathrm{p}>0.10)$. The covariance model for repeated measurements were selected based on Akaike information criterion (AIC). The adjust Tukey test was used for multiple treatment comparisons using the LSMEAN statement of SAS (SAS Institute, Cary, NC, USA). For the different statistical tests, significance was declared at $\mathrm{p} \leq 0.05$ and trends at $\mathrm{p} \leq 0.10$, unless otherwise stated.

\section{RESULTS}

Mineral and heavy metals concentration in DAP and DCP containing diets

Fertilizer grade DAP contained 19.7 and 185.4 respectively $\mathrm{Ca}$ and $\mathrm{P}(\mathrm{g} / \mathrm{kg})$ and $14,623.3 \mathrm{ppm}$ fluorine, while DCP contained 230.3 and 195.2 respectively $\mathrm{Ca}$ and $\mathrm{P}(\mathrm{g} / \mathrm{kg})$ and 1,039.1 ppm fluorine (Table 1). The DCP contained more lead, while concentration of mercury, cadmium and arsenic were similar compared with DAP. The solubility of $\mathrm{P}$ in acid was similar for DAP and DCP. The diet with DAP contained $60 \mathrm{ppm}$ fluorine while the diet with DCP contained 13 ppm fluorine (Table 2). Both experimental diets had similar $\mathrm{Ca}, \mathrm{P}$, and other nutrients measured (Table 2).

\section{Animal performance}

Lambs fed the diet with DAP tended to have greater daily DM intake during experiment compared to those fed the diet with DCP ( $=0.09$; Table 3$)$. Average daily gain, final BW, BW change and feed conversion ratio were similar between lambs fed the two dietary treatments. Daily DM intake and BW in-
Table 2. Ingredients and chemical composition of experimental diets fed to finishing lambs

\begin{tabular}{|c|c|c|}
\hline Items & DCP & DAP \\
\hline \multicolumn{3}{|l|}{ Ingredients ( $\mathrm{g} / \mathrm{kg}$ of dry matter) } \\
\hline Wheat straw & 350 & 350 \\
\hline Beet pulp & 320 & 320 \\
\hline Corn grain & 170 & 170 \\
\hline Barley grain & 100 & 100 \\
\hline Soy bean meal & 50 & 50 \\
\hline DAP & - & 3.45 \\
\hline DCP & 3.83 & - \\
\hline Urea & 2.95 & 1.56 \\
\hline $\mathrm{CaCO}_{3}$ & - & 2.15 \\
\hline $\mathrm{NaCl}$ & 2.50 & 2.50 \\
\hline Filler & 0.72 & 0.34 \\
\hline \multicolumn{3}{|c|}{ Nutrients profile and chemical composition ( $\mathrm{g} / \mathrm{kg}$ of dry matter) ${ }^{1)}$} \\
\hline Metabolisable energy (Mcal/kg DM) ${ }^{1)}$ & 2.38 & 2.38 \\
\hline Crude protein ${ }^{11}$ & 106 & 106 \\
\hline Acid detergent fiber ${ }^{1)}$ & 325 & 325 \\
\hline Neutral detergent fiber ${ }^{1)}$ & 455 & 455 \\
\hline Ether extract ${ }^{1)}$ & 18.4 & 18.4 \\
\hline Non-fiber carbohydrates ${ }^{1)}$ & 356 & 356 \\
\hline Ash & 65.6 & 65.3 \\
\hline Calcium & 3.59 & 3.59 \\
\hline Phosphorus & 2.45 & 2.45 \\
\hline Calcium:phosphorus & 1.47 & 1.47 \\
\hline P from DAP or DCP ( $\mathrm{g} / \mathrm{kg}$ of total $\mathrm{P})$ & 261 & 305 \\
\hline \multicolumn{3}{|l|}{ Heavy metals (ppm) } \\
\hline $\mathrm{F}$ & 13.0 & 60.0 \\
\hline $\mathrm{Pb}$ & 0.57 & 0.46 \\
\hline $\mathrm{Hg}$ & 0.06 & 0.09 \\
\hline $\mathrm{Cd}$ & 0.09 & 0.09 \\
\hline As & 0.88 & 0.89 \\
\hline
\end{tabular}

creased with advancing lamb age $(\mathrm{p}<0.05)$. Average daily gain and feed conversion ratio remained similar over the 93 days measurement period.

There was a dietary treatment $\times$ time period interaction $(\mathrm{p}<$ 0.05 ; Table 4) for DM and organic matter digestibility. At day $30, \mathrm{DM}$ and organic matter digestibility were greater in lambs fed the diet with DCP compared with DAP $(\mathrm{p}<0.05)$, while at days 60 and 90 of the trial, DM and organic matter digestibility were similar for lambs fed the two dietary treatments. Fecal P concentration was lower for lambs fed the diet with DAP than for lambs fed the diet with DCP at day 90 of the experiment $(\mathrm{p}<0.05$; Table 4$)$. Apparent digestibility of $\mathrm{P}$ was greater for lambs fed the DAP diet compared with lambs fed DCP diet $(\mathrm{p}<0.05$; Table 4$)$.

\section{Blood metabolites}

Serum urea and plasma Ca were similar between lambs fed diets with DAP and DCP (Table 5). Feeding the diet with DAP 
Table 3. Dry matter intake (DMI) and performance of finishing lambs fed a diet supplemented with either di-calcium phosphate (DCP) or di-ammonium phosphate (DAP) as the phosphorous source during a 93 day period

\begin{tabular}{|c|c|c|c|c|c|}
\hline \multirow{2}{*}{ Items } & \multicolumn{5}{|c|}{ Parameters } \\
\hline & DMI (kg/d) & ADG $(\mathrm{kg} / \mathrm{d})$ & BW (kg) & BWC (kg) & FCR (kg DM/kg ADG) \\
\hline \multicolumn{6}{|l|}{ Treatments } \\
\hline $\mathrm{DCP}$ & 1.16 & 0.161 & 33.85 & 2.48 & 8.44 \\
\hline DAP & 1.22 & 0.182 & 34.37 & 2.79 & 7.25 \\
\hline SEM & 0.023 & 0.0108 & 0.248 & 0.152 & 0.603 \\
\hline$p$-value & 0.09 & 0.17 & 0.15 & 0.18 & 0.17 \\
\hline \multicolumn{6}{|l|}{ Periods (d) } \\
\hline $0-15$ & $0.98^{c}$ & 0.142 & $28.00^{f}$ & $2.98^{\mathrm{ab}}$ & 7.30 \\
\hline $16-30$ & $1.08^{c}$ & 0.167 & $29.50^{\mathrm{e}}$ & $1.51^{c}$ & 6.79 \\
\hline $31-45$ & $1.15^{b}$ & 0.173 & $31.91^{d}$ & $2.42^{b}$ & 8.55 \\
\hline $46-60$ & $1.16^{b}$ & 0.194 & $35.73^{c}$ & $3.50^{\mathrm{a}}$ & 6.53 \\
\hline $61-75$ & $1.33^{\mathrm{a}}$ & 0.161 & $38.33^{b}$ & $2.57^{b}$ & 9.35 \\
\hline $76-90$ & $1.43^{b}$ & 0.189 & $41.19^{a}$ & $2.84^{\mathrm{ab}}$ & 8.36 \\
\hline SEM & 0.039 & 0.0178 & 0.413 & 0.252 & 1.045 \\
\hline p-value & $<0.0001$ & 0.36 & $<0.0001$ & $<0.0001$ & 0.32 \\
\hline \multicolumn{6}{|c|}{ Treatment $\times$ period } \\
\hline p-value & 0.87 & 0.93 & 0.99 & 0.91 & 0.64 \\
\hline
\end{tabular}

$A D G$, average daily gain; $B W C$, body weight change; $F C R$, feed conversion ratio calculated as dry matter intake/weight gain; SEM, standard error of means.

Means with different letter (a-f) within column differ $p<0.05$.

increased plasma $P$ and serum alkaline phosphatase enzyme $(\mathrm{p}<0.05)$ compared with feeding the diet with DCP. There was a dietary treatment $\times$ time period interaction $(\mathrm{p}<0.05)$ for serum glucose. At day 60 of feeding DAP, serum glucose was greater compared with feeding DCP $(\mathrm{p}<0.05)$, while serum glucose was similar at the other sampling times for lambs fed either DAP or DCP (Table 5). Blood metabolites changed as the age of lambs increased (Table 5). Lambs had lower blood glucose at day 90 compared with days 30 and 60 ( $\mathrm{p}<0.0001)$, lower blood urea and $\mathrm{P}$ at day 60 compared with days 30 and $90(\mathrm{p}<0.0001)$ and higher blood alkaline phosphatase concentration at day 90 compared with day 30 and 60 (p<0.0001).
Lambs had lower blood Ca at day 30 compared with day 90 , which were both lower than on day $60(\mathrm{p}<0.0001)$.

\section{DISCUSSION}

Lambs fed the diet with DAP tended to have a greater DM intake than those fed the diet with DCP in the current study, which was opposite to findings of Oltjen et al [6] who reported that feeding DAP decreased DM intake of finishing lambs. The DAP source used in the current study was in a powder form while DAP was in a granule form in the study of Oltjen et al [6]. Adding DAP as powder likely improved mixing with the

Table 4. Dry mater, organic matter and phosphorous apparent total tract digestibility (\%) and fecal phosphorous concentration ( $\mathrm{g} / \mathrm{kg}$ DM) of finishing lambs fed a diet supplemented with either di-calcium phosphate (DCP) or di-ammonium phosphate (DAP) as the phosphorous source

\begin{tabular}{|c|c|c|c|c|}
\hline \multirow{2}{*}{ Treatments } & \multicolumn{4}{|c|}{ Parameters } \\
\hline & Dry matter digestibility & Organic matter digestibility & Fecal phosphorous concentration & Phosphorous digestibility \\
\hline $\mathrm{DCP}$ & 67.9 & 71.2 & $3.8^{\mathrm{a}}$ & $50.2^{\mathrm{a}}$ \\
\hline DAP & 66.8 & 70.2 & $3.1^{b}$ & $58.7^{b}$ \\
\hline SEM & 0.59 & 0.62 & 0.18 & 1.85 \\
\hline $\mathrm{p}$-value & 0.19 & 0.25 & $<0.05$ & $<0.05$ \\
\hline \multicolumn{5}{|l|}{ Days of sampling } \\
\hline 30 & 669 & 702 & - & - \\
\hline 60 & 682 & 713 & - & - \\
\hline 90 & 669 & 707 & - & - \\
\hline SEM & 7.2 & 7.6 & - & - \\
\hline p-value & 0.35 & 0.76 & - & - \\
\hline Treat $\times$ time $^{1)}$ & $<0.01$ & $<0.05$ & - & - \\
\hline
\end{tabular}

SEM, standard error of means.

1) At day 30, lambs fed with DCP had greater dry matter and organic matter digestibility $(p<0.05)$.

Means with different letter $(a, b)$ within column differ $p<0.05$. 
Table 5. Blood metabolite profile in finishing lambs fed a diet with either di-calcium phosphate (DCP) or di-ammonium phosphate (DAP) as a P source during 93 days

\begin{tabular}{lccccc}
\hline Items & Glucose $(\mathbf{m g} / \mathbf{d L})$ & Urea $(\mathbf{m g} / \mathbf{d L})$ & Calcium $(\mathbf{m g} / \mathbf{d L})$ & Phosphorous $(\mathbf{m g} / \mathbf{d L})$ & Alkaline phosphatase $($ IU/L) \\
\hline Treatments & & & & & \\
DCP & 59.42 & 8.74 & 9.03 & $4.76^{\mathrm{b}}$ & $626.7^{\mathrm{b}}$ \\
DAP & 61.06 & 8.28 & 8.96 & $4.99^{\mathrm{a}}$ & $741.2^{\mathrm{a}}$ \\
SEM & 1.536 & 0.53 & 0.068 & 0.071 & 35.36 \\
p-value & 0.46 & 0.54 & 0.42 & 0.03 & 0.03 \\
Day of sampling & & & & & $647.7^{\mathrm{b}}$ \\
30 d & $65.67^{\mathrm{a}}$ & $10.92^{\mathrm{a}}$ & $8.20^{\mathrm{c}}$ & $5.44^{\mathrm{a}}$ & $606.1^{\mathrm{b}}$ \\
62 d & $69.70^{\mathrm{a}}$ & $6.57^{\mathrm{b}}$ & $9.54^{\mathrm{a}}$ & $3.71^{\mathrm{b}}$ & $898.1^{\mathrm{a}}$ \\
93 d & $45.35^{\mathrm{b}}$ & $7.87^{\mathrm{a}}$ & $9.24^{\mathrm{b}}$ & $5.47^{\mathrm{a}}$ & 41.31 \\
SEM & 1.882 & 0.649 & 0.083 & 0.088 & 0.01 \\
p-value & $<0.0001$ & $<0.0001$ & $<0.0001$ & $<0.0001$ & 0.57 \\
Treat $\times$ time & 0.043 & 0.33 & 0.75 & 0.09 & \\
\hline
\end{tabular}

SEM, standard error of means.

Means with different letter (a-c) within column differ $p<0.05$.

concentrates, which might improve the diet palatability and reduce feed selection and sorting by sheep. Oltjen et al [6] reported that including DAP in pelleted concentrate rather than in granule form would increase its intake and palatability. Further, only $261 \mathrm{~g} / \mathrm{kg}$ of total $\mathrm{P}$ of diet was supplied by DAP in current study, while Oltjen et al [6] supplied $940 \mathrm{~g} / \mathrm{kg}$ of $\mathrm{P}$ in the diet as DAP. The amount of DAP supplemented in the diet might affect the palatability of the diet. Phosphorus is involved also in the control of appetite (in a manner not yet fully understood) and in the efficiency of feed utilization [17].

Average daily gain and feed conversion ratio were similar for lambs fed DAP and DCP in the current study. Venediktove et al [18] reported that feeding a diet supplemented with DAP improved weight gain and feed efficiency in calves compared with feeding DCP and Karadzyan et al [19] reported that feeding DAP improved weight gain in steers. Karadzyan et al [19] indicated that $P$ from DAP had greater bioavailability than P from DCP, which was also found in the current study with lambs fed with DAP having lower fecal $P$ and higher plasma $\mathrm{P}$, which indicated that $\mathrm{P}$ from $\mathrm{DAP}$ had a greater bioavailability. Phosphorus concentration in feces is affected by endogenous losses and amount of $\mathrm{P}$ intake $[2,20,21]$ and plasma $\mathrm{P}$ is strongly related to amount of $\mathrm{P}$ intake and the bioavailability of $P$ resources $[4,15]$. The DM intake of lambs fed DAP and DCP were similar and therefore the difference in fecal and plasma $\mathrm{P}$ concentrations were likely not affected by level of intake. Annenkove et al [22], Bogdani et al [23] and Suttle [2] reported also higher bioavailability of P from DAP compared with P from DCP.

The diet ingredients provided 739 and $695 \mathrm{~g} / \mathrm{kg}$ of $\mathrm{P}$ lamb requirements and 261 and $305 \mathrm{~g} / \mathrm{kg}$ of $\mathrm{P}$ requirements were provided by DAP and DCP respectively. The lack of lamb performance responses in the current study might be due to the low inclusion level of DAP and DCP or lamb requirements might have been met independent of bioavailability. A phos- phorus deficiency may be observed by slow growth, declined appetite, unthrifty appearance, listlessness, low level of phosphorus in blood (less than $4 \mathrm{mg} / \mathrm{dL}$ of plasma), and development of rickets [4], which were all not the case with either P supplement in the diet. Further, digestibility of DM and organic matter was lower in lambs fed DAP than in lambs fed DCP ( $648.0 \mathrm{vs} 690.0$ and $681.0 \mathrm{vs} 723.0 \mathrm{~g} / \mathrm{kg}$ ) at the end of first period $(30 \mathrm{~d})$, which was likely due to the greater DM intake of lambs fed DAP that can result in decreased nutrient digestibility [4]. Energy intake and availability were therefore likely similar between the two diets, another likely reason why lamb performance was similar.

Feeding DAP increased serum alkaline phosphatase in lambs. Alkaline phosphatase activity gives a good indication of the extent of new bone formation and osteoblast activity [24] and was found to be decreased under poor feeding conditions in young sheep, which may influence growth rate [25].

One concern about using of fertilizer grade DAP is its fluorine content, which if fed at high levels can exerts a cumulative toxic effect. Oltjen et al [6] reported that feeding 88 grams DAP (fluorine concentration not provided) in the diet of sheep with a BW of $45 \mathrm{~kg}$ resulted in toxic effects. Phosphorus to fluorine ratio in DAP used in the current study was 12.7 , which was lower than the threshold of 120 recommended for minimizing the risk of fluorosis toxicity when using $P$ sources $[4,2]$. With the inclusion of DAP to provide $261 \mathrm{~g} / \mathrm{kg}$ of total P in the diet, however, the fluorine concentration of diet reached $60 \mathrm{ppm}$ which has been reported as the maximum tolerable level for breeding sheep [4]. A de-fluorination procedure may decrease the fluorine concentration in DAP. Phosphorus resources can also contain heavy metals at toxic levels, which can be hazardous for the animal health [2]. The concentration of potential toxic elements in diets with either DAP or DCP in the current study were, however, below hazardous threshold levels for ruminants [26] and will therefore be safe 
to feed at the DAP and DCP inclusion levels used.

\section{CONCLUSION}

DAP had lower $\mathrm{P}$ and higher $\mathrm{N}$ and fluorine compared with DCP. Using DAP to supply $261 \mathrm{~g} / \mathrm{kg}$ of total diet phosphorous instead of DCP did not affect the growth and feed conversion efficiency in finishing lams. Greater plasma $\mathrm{P}$ and lower fecal $\mathrm{P}$ concentration in lambs fed DAP indicate greater $\mathrm{P}$ bioavailability from DAP than from DCP in finishing lambs.

\section{CONFLICT OF INTEREST}

We certify that there is no conflict of interest with any financial organization regarding the material discussed in the manuscript. Jonker A is an employee of AgResearch Ltd. company.

\section{ACKNOWLEDGMENTS}

Authors thank Mr. Ruzbahani, the head of Honarestan Keshavarzi of Samen, Malayer, for providing space and individual boxes for lambs in this study.

\section{REFERENCES}

1. National Research Council (NRC). Nutrient requirements of small ruminants: Sheep, Goats, Cervids, and New World Camelids. Washington, DC, USA: National Academies Press; 2007.

2. Suttle NF. Mineral nutrition of livestock, 4th Edition. Wallingford, UK: CAB International; 2010.

3. Russell EL, Hale WH, Farris Hubbert J. Evaluation of diammonium phosphate as a source of nitrogen for ruminants. J Anim Sci 1962;21:523-6.

4. National Research Council (NRC). Nutrient requirements of sheep. Washington, DC, USA: National Academies of Press; 1985.

5. Prasad R, Agrawal IS, Verma ML. The effect of lime treatment of wheat straw and its supplementation with diammonium phosphate on growth in heifers. Indian J Anim Nutr 1985;2: 114-9.

6. Oltjen RR, Waller GR, Nelson AB, et al. Ruminant studies with diammonium phosphate and urea. J Anim Sci 1963;22:3642.

7. Iranian Council of Animal Care. Guide to the care and use of experimental animals. Vol. 1. Isfahan, Iran: Isfahan University of Technology; 1995.

8. Association of Official Analytical Chemists. Official methods of analysis of AOAC, 16th edn. Arlington, VA: Association of Official Analytical Chemists International; 1995.

9. Van Keulen J, Young BA. Acid insoluble ash as a natural marker for digestibility studies. J Anim Sci 1977;44:282-7.

10. Jorhem L. Determination of metals in foods by atomic absorption spectrometry after dry ashing: NMKL collaborative study. J AOAC Int 2000;83:1204-11.

11. Bauer PJ. Affinity and stoichiometry of calcium binding by arsenazo III. Anal Biochem 1981;110:61-72.

12. Goodwin, JF. Quantification of serum inorganic phosphorus, phosphatase and urinary phosphate without preliminary treatment. Clin Chem 1970;16:776-80.

13. Saifer A, Gerstenfeld S. The photometric microdetermination of blood glucose with glucose oxidase. J Lab Clin Med 1958; 51:448-60.

14. Tietz NW. Clinical Guide to Laboratory Tests, 3rd ed. Philadelphia, PA, USA: W. B. Saunders; 1995.

15. Klin Z. Recommendation of the German Society of Clinical Chemistry. Standardization of methods for measurement of enzymatic activities in biological fluids. Chem Klin Biochem 1972;10:182-91.

16. Statistical Analysis System. SAS user's guide: statistics $9.2 \mathrm{ed}$. Cary, NC, USA: SAS Institute; 2003.

17. Ternouth JH. Endogenous losses of phosphorus by sheep. J Agric Sci 1989;113:291-7.

18. Venediktov AM, Magomedov MS, Grishin FA. Ammoniated monocalcium phosphate as a supplement for livestock. Khimiya v Sel' skom Khozyaistive 1973;10:786-8.

19. Karadzhyan AM, Kagramanayan DA, Markaryan GS. Combinend effect of natural zeolite and diammonium phosphate on growth of fattening bull calves. Trudy erevanskogo zooveterinarnogo institute 1987;60:32-4.

20. Dias RS, Silva T, Pardo RMP, et al. Rumen phosphorus metabolism in sheep. J Agric Sci 2009;147:391-8.

21. Dias RS, Lopez S, Patino RMP, et al. An extended model of phosphorus metabolism in growing ruminants. J Anim Sci 2011;89:4151-62.

22. Annenkov BN, Dukhin IP, Madison VL, et al. Phosphorous metabolism in calves on different rations. Doklady Vsesoyuznoi Ordena Lenina Akademii Sel Sroknozyaistvennykh Nauk 1973;6:28-30.

23. Bogdani DH, Habibi S, Sejdari I. Role of diammonium phosphate in balancing protein and mineral content in the feed for rearing beef cattle. Buletini I Shkecave Zooternike e Veterinare 1983;1:23-33.

24. Van Straalen JP, Sanders E, Prummel MF, et al. Bone-alkaline phosphatase as indicator of bone formation. Clin Chim Acta 1991;201:27-34.

25. Healy PJ. Serum alkaline phosphatase in sheep. Clin Chim Acta 1971;33:431-6.

26. National Research Council (NRC). Mineral tolerances of animals, 2nd edn. Washington, DC, USA: National Academy of Sciences; 2005. 